\title{
The Advantages of Critical and Systematic Literary Taxonomies: A Review Article of New Work by Cerquiglini, Juvan, and Zima
}

\author{
Kristof Jacek Kozak \\ University of Alberta
}

Follow this and additional works at: https://docs.lib.purdue.edu/clcweb

C.

Part of the Comparative Literature Commons, and the Critical and Cultural Studies Commons

Dedicated to the dissemination of scholarly and professional information, Purdue University Press selects, develops, and distributes quality resources in several key subject areas for which its parent university is famous, including business, technology, health, veterinary medicine, and other selected disciplines in the humanities and sciences.

CLCWeb: Comparative Literature and Culture, the peer-reviewed, full-text, and open-access learned journal in the humanities and social sciences, publishes new scholarship following tenets of the discipline of comparative literature and the field of cultural studies designated as "comparative cultural studies." Publications in the journal are indexed in the Annual Bibliography of English Language and Literature (Chadwyck-Healey), the Arts and Humanities Citation Index (Thomson Reuters ISI), the Humanities Index (Wilson), Humanities International Complete (EBSCO), the International Bibliography of the Modern Language Association of America, and Scopus (Elsevier). The journal is affiliated with the Purdue University Press monograph series of Books in Comparative Cultural Studies. Contact: <clcweb@purdue.edu>

\section{Recommended Citation}

Kozak, Kristof Jacek. "The Advantages of Critical and Systematic Literary Taxonomies: A Review Article of New Work by Cerquiglini, Juvan, and Zima." CLCWeb: Comparative Literature and Culture 2.4 (2000): <https://doi.org/10.7771/ 1481-4374.1097>

This text has been double-blind peer reviewed by $2+1$ experts in the field.

The above text, published by Purdue University Press @Purdue University, has been downloaded 3335 times as of 11/ 07/19. Note: the download counts of the journal's material are since Issue 9.1 (March 2007), since the journal's format in pdf (instead of in html 1999-2007).

This document has been made available through Purdue e-Pubs, a service of the Purdue University Libraries. Please contact epubs@purdue.edu for additional information.

This is an Open Access journal. This means that it uses a funding model that does not charge readers or their institutions for access. Readers may freely read, download, copy, distribute, print, search, or link to the full texts of articles. This journal is covered under the CC BY-NC-ND license. 


\section{PURDUE}

UNIVERSITY PRESS <http://www.thepress. purdue.edu>

\section{CLCWeb: Comparative Literature and Culture}

ISSN 1481-4374 <http://docs.lib.purdue.edu/clcweb> Purdue University Press @Purdue University

CLCWeb: Comparative Literature and Culture, the peer-reviewed, full-text, and open-access learned journal in the humanities and social sciences, publishes new scholarship following tenets of the discipline of comparative literature and the field of cultural studies designated as "comparative cultural studies." In addition to the publication of articles, the journal publishes review articles of scholarly books and publishes research material in its Library Series. Publications in the journal are indexed in the Annual Bibliography of English Language and Literature (Chadwyck-Healey), the Arts and Humanities Citation Index (Thomson Reuters ISI), the Humanities Index (Wilson), Humanities International Complete (EBSCO), the International Bibliography of the Modern Langua-ge Association of America, and Scopus (Elsevier). The journal is affiliated with the Purdue University Press monog-raph series of Books in Comparative Cultural Studies. Contact: <clcweb@purdue.edu>

Volume 2 Issue 4 (December 2000) Book Review Article Kristof Jacek Kovak,

"The Advantages of Critical and Systematic Literary Taxonomies: A Review Article of New Work by Cerquiglini, Juvan, and Zima"

<http://docs.lib.purdue.edu/clcweb/vol2/iss4/14>

Contents of CLCWeb: Comparative Literature and Culture 2.4 (2000)

<http://docs.lib.purdue.edu/clcweb/vol2/iss4/> 


\section{Kristof Jacek KOZAK}

The Advantages of Critical and Systematic Literary Taxonomies: A Review Article of New Work by Cerquiglini, Juvan, and Zima

The ensuing review article discusses the following three works of literary criticism: Peter V. Zima's The Philosophy of Modern Literary Theory (London: Athlone, 1999); Marko Juvan's Intertekstualnost (Intertextuality) (Ljubljana: Drzavna zalozba Slovenije, 2000), and Bernard Cerquiglini's In Praise of the Variant: A Critical History of Philology. Trans. Betsy Wing (Baltimore: The Johns Hopkins UP, 1999). Although these texts may not seem to have many elements in common, their efforts all go towards painstakingly putting together syntheses in their respective fields. Zima offers a synthesis of literary theory on the metatheoretical level, Juvan succeeds in writing a synthesis of sundry configurations of intertextuality, and Cerquiglini offers a historical synthesis of philological literary discipline and exerts its critique on the case of medieval chansons de geste. In contemporary times of predominantly "small" narratives such undertakings are to be, in my opinion, more than welcome.

It may be considered already a locus communis of contemporary North American literary scholarship that one is confronted with quite a hard-line stance, which, uttered in a disarmingly uncomplicated manner, seems to be antagonistically disposed towards certain aspects of the continental theoretical tradition. Indeed, it is generally thought to be a "given" that prior paradigms have either become obsolete or redundant. It is to spite those scholars and to open again larger horizons that Peter V. Zima addresses these contentions in his recent The Philosophy of Modern Literary Theory. Zima does not seem to contest the popularity of such exclusivist theoretical stances which were fully and without reservation adopted by the mentioned theoretical circles. However, being aware of the transiency of those fashions, Zima is, to be sure, bent on not only respecting the theoretical tradition but including it amid his hypotheses. Namely, past and present are inseparably intertwined in the hermeneutic circle: One cannot understand present without the past and vice versa. This is why, Zima maintains, negating our own theoretical past is a highly unproductive theoretical approach. Thus, he says, "modern theories of literature can only be understood adequately if they are considered within the philosophical and aesthetic context in which they originated and evolved. As long as they are isolated from this context and viewed in purely literary terms, as co-existing and competing approaches to literature, their specific character and their fundamental aims are obscured" (vii). For it is clear that the presently fashionable ideas, such as poststructuralism, deconstruction, reader's response theories etc., did not evolve in the intellectual vacuum but, in many if not all cases, the seeds of divergent thinking sewn on the fertile ground of previous hypotheses that made them incarnate. And negatio, to a certain extent, affirmatio est, which is why it is not possible to claim the complete severing of ties with the past altogether.

Zima's position, however, is not to negate either of them, but to try to bridge the chasm between the two incompatible approaches. As will be explained later, the author tries to find and to establish as a firm foundation for a new literary theory "textual elements of structures beyond collectively sanctioned ideological stereotypes" (ix), in other words, the components that are, without any contention, present in any and every work of art. Being aware of that, as well as of the fact that not all theoretical stances support his unique method, Zima tries to draw the line between the philosophically and aesthetically "essence-oriented" theories and sociologically based ones, including: cultural and post-colonial studies, New Historicism, and feminist criticism. Because of the fact that their field of interest lies in larger sociological, cultural, economic and political realms, the letter theories cannot, Zima asserts, "be understood as aesthetic theories" (ix). Zima is bent on recovering the epistemological frame of reference of the former, regardless of the fact that they seem to have in the contemporary world lost their initial appeal and remained stored in the back-room of history to be referred to only in the case of archeological literary inquiry (the Hegelian metaphor about Minerva's owl seem more than adequate again). Zima can, in my opinion, pride himself on approaching the discussed essentialist literary theories with great sensibility. He does not simply attribute one theory to one cognitive attitude or one hermeneutic 
tradition and hence, stretch them on the Procrustus' bed but, on the contrary, with epistemological rafinement purifies components from the thicket of entire theories and assigns them to either of the three basic theoretical strands, or even to two of them at the same time.

Commencing $a b$ ovo, Zima posits the essential question as "to what extent literary texts (works of art in general) univocally express conceptual thought or meaning"? (1). This, being on the one hand the essential question of ontologically oriented literary theories, has on the other always been the paramount riddle of philosophical epistemology, namely the problem of conceptualization of works of art, or even their essence. Thus, it becomes evident to what extent literary theory and philosophy are interwoven in hermeneutics of a (literary) work of art. Philosophy, in fact, avails itself in the form of a hermeneutic tool for the vast majority of literary theories. The author's point of departure, the one in which philosophy and literary theory also converge, reveals itself in the Saussurian concepts of signifiant and signifié? later reworked by Hjelmslev into the expression and the content planes of language. Zima finds complements to the two mentioned planes in German idealistic philosophy, most notably that of Kant and his theoretical adversary, Hegel. Kant and Hegel did not use the linguistic terminology, this was done by their successors. This is why it is "perfectly possible to speak of Kantian and Hegelian positions within the contemporary literary theory" (3). There exists a correspondence with the duality of Kantian gnoseology because of "the assumption that aesthetic knowledge cannot be reduced to conceptual knowledge" (3). Drawing on Kant's celebrated four aporetic definitions of the Beautiful as a "disinterested pleasure," or "purposiveness without purpose," he perspicaciously establishes the first general taxonomic paradigm, where the said concept, comparably to the expression plane, cannot be reduced to and encompassed by rational concepts. There always is a remainder which stands for something "extra-conceptual," something existing beyond rational logic, something one should, in Wittgensteinian manner, only "be silent" about (see Wittgenstein 189). Yet, Zima is quick to warn this does not mean an automatic call for an arbitrary and fully voluntary explanation, on the contrary, insofar as one shapes this category one has to be aware that there a concept still exists, albeit "only" as an indefinable one. Such a stance is particularly important because it bears upon another category of overwhelming importance, that of the autonomy of art in general. Autonomy of art is the concept introduced by the formation of bourgeois society, most notably two of its artistic currents: Enlightenment and Romanticism. Both were supported by one of the intellectual currents of German idealism. Much as this artistic notion of independence and, hence, also autonomy had a significant influence, it was of a rather short life-span. In the twentieth century, particularly after the collapse of historical avantgardes with their revolutionary intentions, art became prey to an all-encompassing corporate form of capitalism together with its commodification and commercialization of any and all artistic endeavors. The idea of art's autonomy came thus to naught. Yet, as far as the theoretical conceptualizations are concerned, the Kantian approach appeared, Zima contends, essential to a number of literary theories, which included the concept of autonomy as their basis. Among them he enumerates Anglo-American New Criticism, Russian Formalism, and Czech Structuralism. These theoretical systems strongly oppose the linking of art to "heteronomous factors such as the author's biography, the social context or the reactions of the reader" (5). Interesting and significant in this particular framework is Ingarden's poetic function, strictly a self-reflexive category of a work of art.

Needless to say, such Kantian attitude was opposed by a fierce Kantian critic, Hegel, who on the other hand, criticized Kant for having "separated the senses (Sinnlichkeit) from the concepts (Begriffe)" (6). Hence, contrary to Kant, art in the Hegelian system of absolute spirit is not the highest form of its "incarnation." This honorable place is in Hegel's system reserved only for philosophy, whereas art remains, in Zima's words, only ancilla philosophiae, which was exactly the opposite of, for example, Schelling's approach. That a work of art is fully subjected to conceptual analysis one can witness in Hegel's definition of a work of art in his Science of Logic. This amounts to supposition of the unity and indivisible totality of the signifier and signified. There is no surplus of the essence which could not be framed with concepts and, consequently, uttered in words. Total conceptualization of art is hardly less than complete subjugation of art to conceptual gnoseology or philosophy. Not art but philosophy is "the highest manner of comprehending the Absolute Idea" 
(Hegel qtd. in Zima 8). Among theories which found the Hegelian approach most appealing Zima enumerates particularly as traditional as well as postmodernist Marxism, Critical Theory, and Frankfurt School. Yet, the two mentioned general vantage points do not satisfy Zima in recapturing the theoretical reality of literary scholarship. Albeit they represent contrary approaches to metaphysics and, consequently, its ensuing forms they nevertheless remain within the circle of European conceptual idealism, the limitations of which have already been noticed and staunchly refuted by the Young Hegelians: Vischer, Feuerbach, Ruge, also Stirner, and Marx. Their critique coincided with a radical negation of entire metaphysical philosophy, that of Nietzsche. Zima, of course, underscores the fact that Nietzsche cannot be seen only as another strand of the Young Hegelians' criticism, even though he might have been influenced by their line of thought. If Hegel's philosophy, as Zima contends, can be perceived as a "secularized quest for truth inspired by Platonic and Christian metaphysics" (14), then Nietzsche efforts aim at the destruction of "the whole metaphysical edifice" (14). Nietzsche aims at revealing the "Emperor's new clothes" of idealistic metaphysics, particularly those of the concept of truth. Consequently, he takes great pains to tear down the entire idealistic systematic philosophy "by revealing the affinity of all opposites and by exposing in a sacrilegious way the vile character of virtue, the evil roots of the morally Good" (14). Nietzsche's answer to the question about what the truth is, is that in our world it is "a mobile army of metaphors, metonymies, antropomorphisms" (15). Likewise, without metaphysical truth a singular analysis of a work of art is no longer possible. Its place is taken by an institutionalized polyvalent and polysemic hermeneutic. The form (expression plane) gains the primary importance at the expense of the content (content plane).

Insofar as Nietzsche's extreme philosophical rejection of the traditionally founded values were to be understood also within art, it was brought to bear on a great importance in the subsequent theories of art (or literature), most notably that of Mikhail Bakhtin's theory of the grotesque, Roland Barthes' poststructuralism, as well as Jacques Derrida's, Paul de Man's, and Geoffrey Harmtan's deconstruction. This short overview, unfortunately, cannot venture into the labyrinth of detailed intricacies of the discussed theories and their interrelations. It will therefore not be possible to render justice to the wealth of intricate and pregnant details discussed. These intricacies remain to be discovered by the reader. Nevertheless, one more important, in fact, paramount undertaking has to be mentioned. In his last chapter Zima leaves the "descripitve, explicative, and critical" realm of his taxonomy behind and ventures independently "towards a critical theory of literature" (189). Ensuing from his text is a fundamental incongruity of the three basic theoretical stances. These paradigms remain contradictory even in the cases of rare vague similarities among them, such as for example an emphasis paid to the expression plane by Kant and Nietzsche. Zima's radical novelty is in suggesting a third, middle way, which can only be that of a synthesis between the two extremes. The foundation of such an amalgamation lies in a presupposition of the "identity of the text ... and some of its salient features" (189). Moreover, here Zima treads a very thin line ... rebours of the entire contemporary literary scholarship, when he says that the new critical literary theory should look for "constant or universally recognizable textual features" (189), be they phonetic, syntactic, or semantic. It is with both poststructuralism, deconstruction in theory and postmodernism in art that every concept, even remotely reminiscent of a totality, wholeness, or universality was banished from the literary theoretical discourse. Yet, this did not procure any new insights about works of art in particular but more about the external issues of art, about the sociology of reception. This is why Zima, fully aware of the said unsolved enigma, dares to propose a "theoretical blasphemy" of this magnitude. This postulated universality does not, of course, in any way lead to a uniformity of artworks. On the contrary, Zima contends, it is beyond this level where theoretical beliefs can find a common level, unitas in pluritate. And here comes the author's main tour de force, namely, this new critical theory is not a static, fixed howbeit critical theory, but rather an unsteady, dialectical movement between two rigid positions, for example between "openness and closure, between polysemy and monosemy, between ... that which escapes a conceptual definition, thus keeping in motion the open-ended process of interpretation" (190). It is hard to disregard the Hegelian roots of the dialectical triad in Zima's suggested theoretical construction. His novelty is in keeping Hegelian sublation (Aufhebung) of the 
thesis and antithesis at bay. The essential "instability" of the synthesis that can be seen only as a vehicle between the two positions is precisely where the importance of his conjecture should be found. This, in turn, leads the reader to the main surmise of the boldly new dialectical literary theory, with which Zima claims for precedent, that is the quest for truth. "The truth if it exists should be looked for in the nexus between that which is definable and that which is not" (190). Truth, a word so much abhorred by contemporary literary scholars (the deconstructionists, reader's response and also intemperate feminist theoreticians), reappears herein as a very much adjustable, albeit perdurable concept in the realm of literary theory. It is commonplace to state that the truth never resides in extremes, yet Zima's theoretical position, together with the newly suggested concept of truth as a triple unity, does exactly that. This is why, in my opinion, his hermeneutic stance, against the long odds of contemporary popularity of extreme theoretical positions, has a good chance for theoretical acceptance and survival, despite the general traits of human character, which finds it much easier to dissect than to synthesize. In order to conceive such an overwhelming system one has to be, as Zima would probably describe himself, at least a Hegelian, not to say an Aristotelian thinker; one has to believe that syntheses are still plausible and viable, if not necessary ways of finding one's way and explaining the maze of literary bailiwick; one has to be convinced that classification of the entire rainbow of existing scholarship still occasions a profound and, moreover, a prescient and seminal insight. In addition to that the ease with which Zima leads the reader through the thicket of the theories coupled with an unbelievably approachable language makes his richly flavored, harmoniously colorful, and puzzlingly tuneful monograph, whose magnitude cannot fail to sincerely impress a truly informative and, because of that, essential lecture for any literary scholar non plus ultra.

Another example of a thorough, comprehensive and skilfully written synthesis that successfully places under one canopy an entire array of modern literary concepts is Marko Juvan's Intertextualnost (Intertextuality). In his comprehensive monograph, Juvan goes against the grain of contemporary literary (postmodern) theory in that he does not atomize and further divide acknowledged concepts but, on the contrary, tries to bring them as close together as possible. Partly this is due to the collection in which his work was published, the Literary Lexicon, a publication of the Institute for Slovenian Literature and Literary Science with the Slovenian Academy of Sciences and Arts, whose name already points at the required encyclopedic and rather taxonomic character of presented topics, and in part to the author's broad knowledge of particular problem of intertextual concepts and paradigms as well as his explicit desire for their exhaustive presentation.

Intertextuality, everyone would agree, is a rather novel theoretical concept burdened with a plethora of meanings, from the original, very broad ones (intertextuality as a societal modus vivendi), to later, rather restricting ones (intertextuality as a cover concept of manifold literary practices of postmodernism). This not only turns into a quite challenging concept to operate with but, moreover, makes the task of its heuristic amalgamation almost an impossible task. It represents a very much contemporary character of literary and theoretical currents, among others poststructuralism and postmodernism, which makes its classification even more difficult. Most fittingly for the concept -- that is, against the post-(Kristeva) or "parastructuralist" (Bakhtin) backdrop -- Juvan addresses intertextuality from both the diachronic as well as the synchronic perspective. Very importantly, and also typical of European scholarship, he does not reject and discard the previous forms of what later has been given a status of an intertextual element, but finds a place for it in his systematic overview. This Juvan does with such a persuasive confidence on the one hand, and broad understanding on the other, that the argument he makes blazes the trail in a truly unobtrusive and convincing way. The general picture Juvan wants his readers to obtain is far from being a unified one for he is aware that intertextuality has its intraliterary as well as its extraliterary implications. Thus, the main rift he notices, similar to the scholarship of Jenny, Grivel, Jardine, Pfister, Markiewicz, Holthuis and others, is between implicit and explicit intertextuality. Juvan prefers to distinguish between a general and specific intertextuality. The "general intertextuality," Juvan suggests, is the characteristic of all texts. It does not pertain only to literature or to certain modes of expression or certain authors. It is, Juvan contends, in fact the 
conditio sine qua non of any text, its existence and readability (52). This broader conception of intertextuality Juvan ascribes to the beginnings of the concept's stellar academic career. Namely, having been introduced at the end of the sixties in France by Kristeva, this understanding received a little of the effervescent even revolutionary, mood of change reigning in many universities in Europe at the time. Hence, intertextuality was at the beginning conceived as something more than just a mere literary concept since it was charged with social implications and connotations. Better yet, according to Kristeva and Barthes, texts do not follow blindly their models, since they actively partake in transforming the "inherited" meaning in order to seek its place within both, the tradition and the present (52). In this vein, poststructuralism set on an extreme course taking away any and all auctorial rights pertaining to the text. Since the author cannot have full control over its reception, he/she cannot pertain to more than just having produced it. The work itself engages in a life of its own. The main task of the text is therefore to produce the meaning which it does in a dynamic way while transgressing the boundaries between the inner (literary) text and the external (societal) reality. Analogously, in Derrida's deconstruction particularly based on Bakhtin's "unmediated reality" it was the world itself as the complex of signs that was turned into a text. At that moment the poststructuralists prided themselves on having grasped the latent revolutionary character of literature and consequently demonstrated also its social dynamism.

Opposite to the broad and general intertextuality, Juvan placed the more limited, specific theoretical notion of intertextuality on the "special characteristics of literature, particular literary genres or literary works" (54) that was developed in the seventies and eighties. Since the general conception was too broad for concrete studies of literary works of art it evolved particularly with regard to the (f)actual analyses. Such notion of intertextuality was formed by virtue of progressive limitations in its field. Initially, the concepts of intertextuality were limited to literature, even poetry as such (Riffaterre, Bloom). The second round of constraining the meaning concentrated on particular mechanisms of literary influences which consequently meant that only specific, singular works of art would allow for the intertextuality (Jenny, Riffaterre, Schmid, Pfister). Athough the two specified definitions may seem at odds with each other, they in fact do not contradict. Juvan specifically talks about (at least) two different levels on which intertextuality may be perceived. From this vantage point the specific version of the concept is nothing less than only a concrete field in which the thicket of general intertextuality comes to being, as the cusp of its multiplicity of manifold forms. Having remained only on the level described so far, Juvan's study would represent a valid study of intertextuality as we know it. Yet, the author offers in concordance with the collection's mentioned title, a truly encyclopedic overview of intertextuality, thus unconditionally demonstrating its continuous presence in literature. Juvan namely provides his readers, in addition to an alluringly presented modern theory of intertextuality, also with its conceptual roots and literary predecessors. Among those he presents the elements found already in the repositories of antiquity, i.e., topoi, loci communes, sentence, motto, allusion, paraphrase, imitation, translation, Menippean satire, travesty, burlesque, etc., and he invites us to pay attention also to the mimesis, competition, remembering, the civilizational dialectics between influence and tradition, together with its harbingers in the form of a quotation, allusion or stylization. Nonetheless, without obfuscating the whole issue, Juvan beacons that the rigid hermeneutics of influence, under which all the mentioned concepts fall, does not manage to do justice to the extravagant cornucopia of intertextuality.

The profuse digression into the "pre-intertextual" past enables Juvan to harken to the modern theoretical voices about intertextuality with a different and unfettered, albeit still perfectly accurate and scrupulous, cognitive sensibility. Regardless of the revolutionary messages that many modern theories have instigated, Juvan's vision enables the construction of a viable paradigm and thus a truly enriching perspective of the multi-perspectival and polimorphous theoretical concept. The entire enterprise undertaken by Juvan would not have achieved its elementary goal had there not been mention of intertextuality and its initial awareness, theoretical reception, and further development in Slovenia. Hence, according to Juvan, the acceptance of the concept of intertextuality in the Slovenian theoretical community has been twofold. On the one hand, an immediate echo to the momentous occasion in France could be noticed whereas on the other, a 
later more elaborate and, at the same time, specific notion made its way into the Slovenian theoretical discourse. The earlier notion attributed to the social, political and cultural situation at the turn from the sixties into seventies, seemed to be linked firmly with the emphatic reception of French poststructuralism and deconstruction in certain Slovenian circles. Thus, a translation of an article by Philippe Sollers occasioned the first mentioning of the concept of intertextuality which occurred only a year after its world-premiere, that is in April of 1968. Needless to say, more translations were under way, particularly those of the works by Kristeva, Derrida, Foucault, and the group Tel Quel. In Slovenia, journals Problemi and Tribuna gathered theoreticians, among whose some later gained great notoriety, like Slavoj Zizek, Mladen Dolar, Rastko Mocnik, Braco Rotar and others, and published the said translations as well as their own essays. Yet, in Slovenia this development took an endemic turn. Some theoreticians, most notably Zizek and Dolar, turned towards materialistic, Marxist readings coupled with Lacan's psychoanalysis of the discursive and social interrelations. The developmental curve of the former spun from Heidegger and phenomenology, through to poststructuralism and deconstruction, in the end arriving at Marxism and Lacanian psychoanalysis. Alluding to Zizek's development, Juvan maintains that, in his opinion, poststructuralism never actually unshackled itself from the influence of structuralism, and moreover, ironically remained the "prisoner of idealism, changing the real life into a universal text" (223). It lead other thinkers, such as Taras Kermauner, into developing new literary formations within Slovenian literature, for example "ludism" and "reism." A different conception, though, appeared with the dawning of the 1980s. From the predominantly philosophical and sociological realms the understanding of the concept shifted, in a parallel way to its evolvement elsewhere, to the literary plane that was at that particular point in time already largely indebted to the insights of postmodernism. Scholars deductively drew on for their studies on the characteristics of the new movement with its literary and discursive intertextual practices. Among those who addressed the intertextuality from the postmodern vantage point were Ale Debeljak, Janko Kos, and Tomo Virk. According to Juvan, for the latter intertextuality is "autoreflexive: it draws attention to the literariness of a narrative text" (228).

Each and every monograph of the Literary Lexicon series was concluded by a section about Slovenian topics. This approach to pay intensive attention to the "local," that is, Slovenia, is in Juvan's book follows from the author's own insight on the meaning of the concept of intertextuality in the study of literature. Needless to say, his vision has been strongly corroborated by its postmodern literary applications; however, he does not seem partisan in his analyses. Having allowed enough time to pass by for relatively safe theoretical conclusions, Juvan is aware that the paramount role of the concept is in revealing the dialogue of literature with literature. In fact, the ontological sine qua non of literature is polyvalent, not to say intertextual. Intertextuality per se appeared to be the condition litterraire, the only way in which literature has been coming into being. It exists on all ontological levels, from the broadest to the most specific ones. At the level of particular influences (literary tropes and figures) the power of its influences variegated through history, does not prevent Juvan from systematizing the influence. Labeling them "index agents" (kazalke), he develops a general system of three agents which may be roughly translated as "description" (opis), "transfer" (prenos), and "imitation" (posnetek). Unfortunately, in this solely introductory article there is not enough room for a detailed description of his system with all its implications. Suffice it to say that Juvan, as it appears, managed to preserve a delicate balance between the broad (intertextual) and narrow (citational) approaches with the three above said concepts, albeit this is not to say that he managed to unravel the Gordian knot and to clear the sometimes hopelessly "murky waters" of intertextuality. Yet, he came very close to mapping the main characteristics of the concept and successfully epitomizing its limitless content. Nevertheless, although the concept of intertextuality has not been formulated before poststructuralism, it became evident that it had been forming a part of our literary, or erudite writing experience since its beginnings. As Juvan very aptly puts it, we became aware of the ubiquitous and certainly forceful presence of intertextuality in the same way as it dawned on Moliére's M. Jourdain in Le bourgeois gentilhomme that he had been uttering nothing short of prose. Literally everything that found its way under the canopy of intertextuality was known since time immemorial and was 
perpetually a part of our more or less learned expressions. This, in fact, is the modus operandi of our human experience. Juvan's text successfully accommodates a truly rare and therefore worthier quality which is his rigor mentis. Although poststructuralist and postmodern theories placed themselves outside the grasp of a historical debate, Juvan is adamant at placing the literary period towards the end of the "history of intertextual phenomena, when literature synthesized what has already been written" (231). Juvan's vision of intertextuality is an all-inclusive and a profoundly systematic one. On more than 320 pages he instrumentally presents the concept of intertextuality in its manifold conceptualizations on the one hand and underscores their essential homogeneity on the hermeneutic level on the other. Without overstatement this encyclopedic overview truly deserves a translation into English and further dissemination in the international realm of academia.

If the first book discussed in the present review is predominantly interested in metatheory, in the coming into being and further existence of theoretical concepts and ideas; if the second paid more attention to the concrete forms of those ideas with examples of literary theory, then the third one reveals a fascinating facet of the relationship between the two: The concepts together with their forms in a particular situation. Originally published in French in 1989 under the title of Eloge de la variante. Historie critique de la philologie, Bernard Cerquiglini's primary interest in In thePraise of the Variant arguably lies in the investigation of one special, singular locus on the path from the multiplicity of artistic ideas (creation) to the multitude of possible readings. The case in point, on which the author chose to examine this focusing of thoughts on the one hand and, again, their dissemination on the other, were chivalresque romances. In other words, epic poems of medieval literature in the light of the investigative literary scholarship. More specifically, with respect to historical literary philology. This essential, yet at the same time limiting and constrictive, focus between the two processes belongs, according to Cerquiglini, to the printed work of art. We should mention here that it was in the period of Romanticism that scholars became increasingly aware of the value of the past and history per se. Their attention shifted to preserving those artifacts. Parallel to the augmented number of museums and galleries, the fixed text, too, received a truly reverent reception. It was being viewed as the memory of humanity. This "carving in stone" of a work of art did not bring about anything but a forcible standstill of a creative process and an artificial fixation of a fluent content in an "absolute" form. That, Cerquiglini argues, is far from corresponding with reality as we know it. His task is thus "to escape the shackles of the fixed text by destabilizing inscriptions" (xi). This case will help Cerquiglini to successfully dispel the "enclosed conformity and authorized stability" (1), of which we, modern readers educated on historical positivist scholarship, consider a text to be. Needless to say, this rigid, absolutist, canonical theoretical stance should be, in Cerquiglini's view, discarded without remorse since it offers misconceptions as well as misrepresentations of the discussed works of art. Not only is this conviction supported by contemporary plurality and multiplicity, two categorial institutions hailed particularly in postmodern literary theory, but it is also aided by the rediscovered importance of the creative process, which is predominantly variable and divergent in character. Namely, the text itself, the unchangeable substantiality permanently printed on paper, opens an entire range of questions about its own origin, conception, epistemological status, meaning etc. Any text carved in stone or, for that matter, printed on paper has been assigned, to certain extent, a more important status because of its permanence. Automatically, regardless of any particular innate or deserved merit, this quality was also translated into the content. Since works of art were perceived as those "whose reliability can be ensured by establishing it" (2), the press, that is the printed form, was given an even more preeminent role which still works today. It has generally come to be seen that if something is printed it means it is good and worth reading. It is, of course, more than obvious to what gross exaggerations this may lead to. According to Cerquiglini, the "final corrected proof is what separates writing from text" (3). The text represents the divergent process of pre-text's creation now momentarily halted and turned into a "stone monument." What Cerquiglini is most disturbed with in this procedure is that the consensual freezing of a creative process in one printed version subsequently gives it the highest value (it is the only one printed), whereas everything written or annotated prior to printing becomes obsolete. 
Cerquiglini does not agree with this standard canonizational process and proves, at least with a certain genre, the necessity of a change in perception. As Cerquiglini attests, the etymology of the word "text" more than furtively hints at its essential position, since the French word "tiste" from around 1120, later changed into texte, did mean "the book of gospels" (35). On the other hand, contemporary literary scholarship became after poststructuralism, Rezeptionstheorie and other sociologically based theories (feminism, gay/lesbian studies, postcolonialism) aware that the text does not correspond to singular readings either. On the contrary, it instigates a multitude of reactions to it. This is why Cerquiglini decided to look for immanent characteristics of text creation and reception outside the text and hence, arrive in a quite Platonic way, at its essence. Even though Cerquiglini is generally correct in his assumptions, a voice of caution should be raised.

In his argument about the terror of the press he follows only the constraining and faulty characteristics of printing as opposed to writing (or the process of it), which in my opinion differ not only formally, but also theologically. If one is a continuing process and the other "only" a onetime retention of a given work of art, this does not take into account the reality in which this way of conveying literature resulted. A continuing process is namely rather difficult to grasp: It is challenging to follow a constantly changing work. In fact, many artists have strived to create one but without success. Thus, in fulfilling a certain telos, a work of art should come as close as possible to the "perfect" fusion of a form and content. In order to support his argument in the fullest, Cerquiglini regresses to the time of joint existence of oral and written literature. The battle between them was a clearly unequal one. For at the beginning, Cerquiglini argues, the "written word, though it might have been precarious and scarce, was a basic value; acknowledged as such, it stood surety for the exchange of ideas just as money" (16). Oral literary tradition, conservative in character, does not have the same power and character as the written one. Oral literature, as soon as it is written, looses the riches it was pregnant with, and becomes depersonified and decontextualized. From the entire rainbow of possible meanings there consensually remains only one, the most obvious and the most logical. The author's personal input is taken away, the work starts a life on its own, regardless of what the author might have added still to the work, since it represents a "deep and defining break between the pre-text and text" (6). The printed work became generally considered as a finite one that should not invite any additional question about author's intentions. Nonetheless, this did not refrain the readers from experiencing a personal reception of the text and hence, from imposing sundry meanings on the text. The authorial figure was irretrievably lost because the "diversity of reactions, situations, and methods did not form any homogeneous concept of the author defined in relation to his text" (4). This situation was, in Cerquiglini's view, further complicated by the augment in the interest of folk literature in the period of Romanticism. Suddenly, scholars found themselves confronted with works of art whose creator was a rather nebulous yet essential entity. The scholars' answer to this new challenge was, as he efficiently shows, inadequate. In order to establish the authority of only one predominant meaning of the past texts (this is valid for both the Antiquity as well as the Middle Ages), a special discipline was created namely, philology. The role it played was that of a literary archeology, dusting off ancient works and assigning them a meaning that it deemed most accurate and legitimate. The problematic case point is that this research of scientific reconstruction of meaning was not always conducted with the greatest concern about the original text. At stake was the significance proper which had been dusted over and then abruptly and without particular fidelity and care brought back to life. Thus, to a certain extent different meanings were reproduced which amounted to sometimes rather odd revelations, to the Jaspersian felix culpa, which was eagerly accepted by philology as a necessary price.

In a separate chapter, Cerquiglini discusses three historical periods of philology, which will here be presented briefly. He names the first period the "empirical" one, which lasted from 1830 until 1860. The most prolific scholar was German Karl Lachmann and his system was considered to be the victory of the mind over the matter. Nevertheless, the era boasted with the least attention to the multiplicity of studied medieval works. The second period, already in France under Gaston Paris lasted from 1860 until 1913, is called a "positive" one since it meant more or less a transposition of Lachmann's theory on the French soil. Finally, the last one, which has remained in 
use since its introduction by Joseph Bédier with his scholarly publication of Jean Renart's Lai de l'Ombre in 1913, is suitably called the period of "doubt." The doubt itself is a very polymorphous entity lending itself greatly to the usage in the scholarship dealing with medieval literary works of art which do not have one fixed version but consist of many different possible readings. After having thoroughly investigated the history of philology, Cerquiglini here connects the past with his own observations, and subsequently, brings all the loose ends together into one firm exemplary texture which he then uses as his essential example. Namely, the author goes to great pains to elucidate the questions about the status of text versus pre-text, the author and his influence on either of them, and the reception and possible re-attributing of the meaning, together with a criticism of initial philological malpractice, all in one literary example, that of "medieval manuscripts written in vernacular" (13). The method Cerquiglini chooses is genetic criticism or literary genetics, which he describes as an "extremely anxious scrutiny of the genesis of a piece of writing" (xi) investigating "the polymorphous activity of writing which precedes the final gesture of the hand" (3). This type of criticism should not, of course, be mixed with literary history which takes into account much larger issues, from sociological and political to personal and psychological, and discusses the development of an entire literary body of a nation, a people or society. It represents, as it were, the entire sum of different singular literary disciplines. Literary genetics is, without any doubt, part and parcel of the former, with its focus running strictly along the lines of the development of a certain literary genre. Genetic criticism has, according to Cerquiglini, two main tasks. If the first is "to return to literature its wealth by assuming the preeminence of writing," then the second is "to point out what, on the order of being or of society, conditions this writing" (xii). Genetic study is not supposed to be concerned with positivistic analysis of obtainable empirical facts but should, by virtue of a pre-textual research, reassemble the plurivocality and spontaneous frivolity of creativeness from the point in time prior to constraining the work of art in the Spanish boot of a printed page. No other literary genre would lend itself better to this kind of analysis than one whose origins reach far back into times of orality, and whose printed or, for that matter, written forms have naughtily kept the plurality of paradigms: The chivalresque romances. In medieval literature the bond between the spoken and the written word was still substantial. It was not before the turn of millennium that oral expression began loosing its primary importance to the written word. Starting with the Carolingian renaissance, the European West was set on an ambitious course of development, one that was founded on writing. Cerquiglini finds the most vigorous examples of the latter "a factor ... in progress and freedom," especially in the "writing in the vernacular" (17). The written word broke very quickly first with Latin and secondly, with its oral tradition, thereby setting itself on a totally new bearing. Yet, as previously stated, this break was not an absolute one, because still present "interventions by the oral were fragmented .... and confirmed in their heterogeneity precisely by the activity of writing" (21). Thus numerous medieval chansons de geste (Perceval, Roman de la Rose, Lai de I'Ombre, Lai de Lanval, Saint Alexis, etc.), even fabliaux, survived in a multitude of quite heterogeneous forms. First, these various versions of the same work of art came to be considered by the philologists of the first and second periods as a misapprehension and a mistake on the path of creation of the text's ideal textual version and, at the same time the "euphoric appropriation by the mother tongue of the gesture that transcends it" (21). Cerquiglini further adds that "this appropriation found expression in an essential variance, which philology, modern thinking about the text, took to be merely a childhood disease, a guilty offhandedness or an early deficiency of scribal culture, whereas the variance was, quite simply, joyful excess" (ibid.). In keeping with this theory, author finds the artificial unity imposed on medieval works by philology in its first two stages as an inappropriate and even harmful enterprise, negating the gist of those texts, that is their "essential plurality" (27), since "in the Middle Ages the literary work was a variable" (33).

Needless to say, philology as positivist discipline educated on canonical Latin texts did pay very little attention to the said medieval literary idiosyncrasy. In this "classical" vein, scholars, most notably Karl Lachmann, were set on the vain quest for the "Holy Grail," that is the reconstructed, "ultimate" form of a romance, a poem, or a play. They essentially misunderstood what medieval 
writing was all about: that the writing and re-writing was at the core of its conception. Different versions of the same work of art with only minuscule differences had not been, as they presumed, mistakes committed by oblivious copyists or mindless scribes but, on the contrary, creative expressions of the fundamentally multi-faceted medieval man, a heritage from the times of orality, where narration of a poem went hand in glove with its (re)creation. Also, they overlooked two basic processes in the conception of this literature: Continuation and repetition. It was not before the last period in the development of philology, the era of "doubt," that the medieval literature was finally brought out of harm's way. This scholarly turnabout was not a simple step to make because it required a complete change of scholarly perception in the traditional philological mindset. Thus, "variance, until the end of the thirteenth century, was the basis of the medieval literary aesthetic, this aesthetic is the perfect antithesis of modern aesthetics of the text" (39). If it is in postmodernism that we can comprehend the full meaning of the change, it was with Bédier that this move in philology occurred. The medieval scribe was not perceived as an inaccurate and confused penman any more, but was instead elevated to the auctorial level. His interventions started being considered on the same level with the primary version. Nonetheless, Cerquiglini does not agree fully with Bédier's approach. In fact, he thinks that the latter did not venture far enough, since "Bédier's antimethod, as much as any other, reduced medieval works to the stable, closed, authorized texts of modernity" (70). Consequently, Cerquiglini suggests, a new, even more decisive approach should be taken.

In bringing this discussion to a close, there seem to be two paramount issues that have arisen from The Praise of the Variant which must be mentioned. The first is the new method, to which Cerquiglini devotes the last three pages, which, in my opinion, draws the main reservation and hence necessitates an evaluation. Namely, if "medieval writing does not produce variants; it is variance" (77), if the "variant is never punctual" (78), and if "variance is the construction of sense" (78), then, Cerquiglini offers the magic cure, "the computer, a valuable aid and one worth considering, provides the obvious solution" (79). This theoretical stance of Cerquiglini's demands a clarification with a few rather lengthy quotations. The author is genuinely fascinated by the presentation of the material which is not "bookish" any more, but "screenic," and in this way epitomizes two essential characteristics: Dialogicality (the screen "offers a constant interaction between the user and the screen"), and multidimensionality ("through the use of windows, it allows one to bring together and consult information belonging to separate entities"). "Utilizing these two qualities, one can conceive of the type of edition that would result from this assembling of separate entities represented by codices. In such an edition, medieval works would no longer be subjected to the two-dimensional and closed structure of the printed page because a diskette could accommodate varied textual masses, which the reader would consult by making them appear in different ways on a computer screen." Furthermore, "the computer is able to help us detect the dynamics of the text by making visible the connections prepared and suggested by the editor" (80). "What the screen provides the reader is an always instantaneous grasp, the ephemeral visualization of different and mobile textual spaces, of texts that are no longer that palpable reality of ink on a page but are only the immateriality of a few electrical pulses" (81). In spite of all the technological advancement of the suggested author's solution, it is a tad disappointing. To convey to some technological means, otherwise considered only a tool, the outcome of a serious scholarly humanistic debate, seems to be a rather simplistic and hasty decision. Computers are, without a doubt, an excellent aid and support in research. They do facilitate work on texts, but they do not bring through their dialogical and multidimensional characteristics any qualitatively new insight. But are the answers to those questions, then, to be found simply in the computer layout (different versions of a poem on a screen)? Can the content truly be understood only with a confrontation of different forms (various version and historical changes against each other)? It goes without saying that to swap the content of research with its form is outright hazardous. Yet, the author's infatuation seems to rest only on this superficial, formal level. His important argument is, first, the quantity of material a floppy disk can carry and, second, the ease with which one receives information: by pressing a button instead of flipping pages. Agreed. But this, consequently, invites another series of questions: whether such a 
difference offers sufficient ground for dismissing the previous "bookish" editions, even if they presented the reader with side by side published diverse versions of a poem or a play? Whether this versatility makes it any easier on the actual reader, since he/she would still have to pay close attention to minute variants of different texts? Or else, whether the computer screen can really offer something in order to enhance the philological comprehension of medieval texts that a printed book cannot? Or, have we simply been confronted with a frivolous obsession and playful fascination with limitless technological possibilities of "electrical pulses"?

The second reservation touches upon the issue of text in general within the process of creation and reception. The two latter ones are both necessarily polyvalent and multi-purpose axiological activities, whereas the nature of the text is to be precisely fixed, regardless of the mistakes made due to errors of omission/commission through printing. Since these are two different realms, they simply cannot be found responsible for successive one-sided presentations, that is publications, of pluriformal medieval chivalresque romances. If the period of the "empirical" philology bore witness to the quite brutal melting of different versions into one called the "proper," or the "perfect" and the "true" one, the fault is not to be found in the Heideggerian ontological difference of the text, but simply in the scholarly approach and later in the reception of it. If the reception of a work of art does not vary in its quantity and scope, then it is not the fault of the printed text (or press, for that matter) but, it is my belief, of the condition sociale, canon, of all kinds of different institutions which regulate the general public's approach to literature. In that case Cerquiglini with press and printed matters attacks a wrong adversary. He does not seem to distinguish between different levels of approach: first, the one of scholarly, scientific reconstruction of the text, and secondly, amateur, rather informative, pleasurable reading. Be that as it may, it is my firm conviction that computers offer less than what meets the eye. Hence, although Cerquiglini's theory of versatility and essential plurality of medieval texts is informative and well developed, it is, in my opinion, rather hard to follow blindly his utter and unconditional infatuation with computers as the ultima ratio of contemporary philological scholarship.

\section{Works Cited}

Benjamin, Walter. Das Kunstwerk im Zeitalter seiner technischen Reproduzierbarkeit. Frankfurt: Suhrkamp, 1963.

Bürger, Peter. Theorie der Avantgarde. Frankfurt: Suhrkamp, 1974.

Cerquiglini, Bernard. In Praise of the Variant: A Critical History of Philology. Trans. Betsy Wing. Baltimore: The Johns Hopkins UP, 1999.

Debeljak, Ale. Relucant Modernity: The Institution of Art and Its Historical Forms. Lanham: Rowman \& Littlefield, 1998.

Jameson, Fredric. Postmodernism, or the Cultural Logic of Late Capitalism. Durham: Duke UP, 1991.

Juvan, Marko. Intertekstualnost (Intertextuality). Ljubljana: Drzavna zalozba Slovenije, 2000.

Wittgenstein, Ludwig von. Tractatus Logico-Philosophicus. London: Harcourt, Brace \& Company, 922.

Zima, Peter, V. "Kulturelle Bedingtheit und kulturelle Vielfalt." Sprachkunst. Beiträge zur Literaturwissenschaft (1999): 121-34.

Zima, Peter V. The Philosophy of Modern Literary Theory. London: Athlone, 1999.

Reviewer's profile: Kristof Jacek Kozak works in comparative literature at the University of Alberta. His research interests include literary theory and the theory of drama, modernist conceptions of art and culture, critical theory and the philosophy of art. He has published numerous articles and translated various texts into Slovene, including Estetski in idejni vplivi na predvojno dramsko in gledalisko kritiko Josipa Vidmarja (Aesthetic and Intellectual Influences on Josip Vimdar's preWorld War II Drama and Theatre Criticism) (1998) and a translation of Szondi's Theorie des modernen Dramas into Slovene as Teorija sodobne drame (Ljubljana: Mestno gledalisce ljubljansko, 2000). Previously, Kozak pursued his studies at the University of Ljubljana, Slovenia, and is currently working towards the completion of his $\mathrm{PhD}$ dissertation on the survival of the tragic subject in modernist drama. E-mail: <kjkozak@ualberta.net>. 